\title{
DEN ALLMÄNNA OPINIONEN, MASSMEDIA OCH RÄTTSSÄKERHETEN
}

\author{
AvP. O. TRÄSKMAN
}

\section{Rättssäkerhet - rättsstatens särmärke}

Av rubrikens tre termer - allmän opinion, massmedia och rättssäkerhet - är rättssäkerheten den som av en jurist tillskrivs den största betydelsen. Rättssäkerheten anges ju vanligen som rättsstatens främsta särmärke och en strävan till absolut rättssäkerhet som ett av de primära målen för all rättslig verksamhet.

Oftast sammankopplas rättssäkerheten med avgörandet i ctt enskilt konkret rättsfall; rättssäkerhet uppfattas vara liktydigt med att formell rättvisa skipas i en viss sak, t.ex. då en domare med iakttagande av stadgat förfarande avgör ett brottmål på basen av gällande straffrättsliga normer. Rättssäkerheten anses bli realiserad genom att gällande materiella normer tilllämpas på avsett sätt i ett förfarande som följer det som reglerats för ifrågavarande fall. Rättssäkerheten förverkligas genom att behörig myndighet meddelar det rättsskydd som förutsätts enligt gällande lag.

Rättssäkerheten kan dock även granskas i ett större sammanhang. Den kan ses som ett syftemål för hela rättssystemet. Ett samhälle utmärks då av rättssäkerhet när samhället som sådant är rättvist, när mao grundläggande mänskliga rättigheter på ett optimalt sätt tillförsäkrats alla dess medlemmar. Rättssäkerheten kan således granskas såväl i relation till formell rättvisa som i relation till materiell rättvisa. ${ }^{1}$ I det förra fallet bedöms rättssäkerheten på basen av existerande rättsliga normer, i det senare fallet på basen av andra normer. Den senare bedömningen blir aktuell' t.ex. vid skapandet av nya rättsliga normer.

Ett av samhällspolitikens viktigaste syftemål är att skapa ett materiellt rättvist samhälle. När kriminalpolitiken - såsom man vanligen gör idag i de nordiska länderna - ses som en del av den allmänna samhällspolitiken, ${ }^{2)}$ blir även kriminalpolitikens syftemål att skapa materiell rättvisa. Detta kan uttryckas, såsom t.ex. den finska straffrättskommittén gjort i sitt betänkande av år 1976, genom att fastställa att kriminalpolitikens uppgift är att bidra till en ökning av välståndet i samhället och till en rättvis fördelning av detta. ${ }^{3)}$ 


\section{Allmän opinion, massmedia och politiska beslut}

När kriminalpolitiken ses såsom en del av den allmänna samhällspolitiken är det befogat att även utgå från att normala regler för politiskt beslutsfattande gäller för de kriminalpolitiska besluten. Ifråga om de viktigaste av dem, d v s de som fattas av behöriga lagstiftningsorgan, gäller därför samma ordning som för övriga lagstiftningsbeslut av samma viktighetsgrad. I de nordiska länderna, såsom även i alla andra borgerliga demokratier, fattas besluten av den folkrepresentation som givits makt att på folkets vägnar stifta lag. Då den lagstiftande makten företräder folket antas att den lag som härigenom kommer till svarar mot folkets vilja, mao står i överensstämmelse med den allmänna opinionen. Rättssäkerhet uppnås genom att gällande statsförfattningsrättsliga regler följs (formell rättvisa) och genom att folkmajoritetens samhälleliga värderingar ges avgörande betydelse (materiell rättvisa). ${ }^{4)}$

I detta system har även massmedia en central roll. Den representativa demokratin förutsätter att medborgarna har möjligheter att kontrollera de beslutsfattande organens verksamhet. Idag sker detta framför allt genom massmedia. Massmedias uppgift är att redogöra för vad som sker i samhället. I denna uppgift ingår att bevaka de beslutande organens verksamhet och sprida information om de beslut som fattas. Massmedierna är det medel som möjliggör den insyn som förutsätts för demokratisk kontroll. Massmedia står därför som garanter för att rättssäkerhet uppnås.

I praktiken är massmedias roll mer komplex. Dagens massmedia nöjer sig sällan med att endast återge verkligheten, mao att så objektivt som möjligt beskriva vad som skett. Som en likvärdig uppgift med denna ser man ofta uppgiften att själv skapa verkligheten, att således på egna villkor skapa det som sker. ${ }^{5)}$ Därtill kommer att massmedia ofta genom att välja ämnen och infallsvinklar som belyser det flyktiga och kittlande skymmer verkligheten genom att det väsentliga förbigås. ${ }^{6)}$

Konsekvenserna av denna splittrade bedömning av massmedias uppgift kan, förenad med den obestridliga maktställning som massmedia har, bli att verkligheten utfaller helt annorlunda än vad idealbilden förutsätter. Istället för att stå som en garant för rättssäkerheten blir massmedia ett hot mot denna.

\section{Beslut avseende kriminalisering och abstrakt straffvärde}

Till de viktigaste kriminalpolitiska besluten på lagstiftningsplanet hör kriminaliseringsbesluten, dvs besluten att belägga en viss gärningstyp med straff. Särskilt i Finland har man försökt utarbeta teoretiska beslutsmodeller för kriminalisering. Utmärkande för dessa är att besluten ses som slutprodukter av rationella överväganden. ${ }^{7)}$

Kriminaliseringsbesluten ingår alltid $\mathrm{i}$ ett led att framtvinga önskvärt 
beteende. Kriminaliseringsbehovet uppstår genom att en viss gärningstyp konstateras ha sådana negativa effekter som man önskar stävja. Då detta vanligen även kan ske på annat sätt än genom att kriminalisera gärningstypen, är kriminaliseringsbeslutet alternativt till andra möjliga åtgärder. Man kan tänka sig att eliminera de negativa effekterna eller minimera dem genom att vidta vissa faktiska åtgärder, eller genom att nyttja annan juridisk reglering än straffrättslig, t.ex. civil- eller förvaltningsrättslig. Vid detta val mellom olika tillbudsstående alternativ tillmäter man ofta stor betydelse åt allmänhetens uppfattning. Vanligen uttrycks detta genom att fastslå att kriminalisering tillgrips och utformas på det sätt som det allmänna rättsmedvetandet förutsätter.

Det allmänna rättsmedvetandet är dock ett mycket vagt begrepp. ${ }^{8)} \mathrm{Om}$ man ger begreppet en empiristisk bestämning (»det allmänna rättsmedvetandet är den empiriskt fastställda allmänna opinionen i en rättslig fråga«) är det visserligen (teoretiskt) möjligt att fastställa dess innehåll. De undersökningar som man gjort i detta avseende har dock ej lett till särskilt entydiga resultat. Som kriterier $\mathrm{i}$ en rationell beslutsprocess är dessa vetenskapligt belagda rön rätt obestämda. ${ }^{9}$

En rent formell beskrivning av lagstiftningsprocessen i samhället ger inte en sann bild av verkligheten. De lagar som stiftas behöver inte svara mot de stiftande organens verkliga åsikter och ej heller mot allmänhetens vilja. ${ }^{10)} \mathrm{I}$ varje samhälle finns grupper som effektivare och bättre än andra kan påverka lagstiftningens utformning. Framför allt den ekonomiska och politiska eliten, men också till en del den intellektuella, kan genom sin aktivitet i betydande mån bestämma det konkreta innehållet $i$ lagarna. Massmedia är ofta redskap för dessa samhällets elitgrupper. Massmedias uppgift kan då bli att ge en bild av att besluten som fattas svarar mot det allmänna bästa. ${ }^{(1)}$

Ifråga om kriminaliseringsbeslut innebär detta t.ex. att straffbeläggande av en viss gärningstyp framställs svara mot (eller stå i strid med) det allmänna rättsmedvetandet. Genom att presentera problemet endast i begränsad utsträckning och med särskild infallsvinkel är det möjligt att skapa en tillräckligt stark allmän opinion för att säkra ett beslut med önskat innehåll. Den allmänna opinion som härigenom skapas tolkas som det allmänna rättsmedvetande som förutsätter det avgörande som önskas. Att avgörandet på basen av en rationell bedömning är felaktigt kan härigenom döljas.

För dem som ser kriminaliseringsbesluten som rationella avgöranden och som idealiserar en teknokratisk beslutsprocess kan detta inte accepteras. Den allmärnna opinion som massmedia företräder framstår då som ett allvarligt hot mot rättssäkerheten. Den finländska kriminologen Patrik Törnudd har varnat för den fara som ligger i att basera kriminaliserings- och andra kontrollpolitiska beslut på opinionsyttringar som har sin grund i populistiska samhällskampanjer: 
Emedan realiserandet av rättvisan förutsätter sans och omdöme utgör även den allmänna debattens kortvariga iver ett hot. I den kriminalpolitiska opinionsbildningen $\mathrm{i}$ vårt grannland Sverige har man under de senaste åren kunnat märka kampanjer som vissa redaktörsgrupper drivit och som utmärkt sig av att tidningarnas nyhets- och reportagespalter har använts för åsiktsstyrning, av en populistisk hets och framför allt av åsiktsspektrets frapperande snävhet: fråga har varit om kampanjer och ej om debatt .... Om en tvärbrant lynchningsmentalitet hotar rättvisan vid domstolsbehandlingen av enskilda fall så kan samma hets på ett ännu ödesdigrare sätt äventyra rättvisan vid bestämmandet av kontrollpolitikens riktning. ${ }^{12)}$

En av kriminalpolitiska orsaker målmedvetet vinklad information är helt självfallet ej den enda orsaken till att massmedia föranleder en felaktig uppfattning om de kriminalpolitiska problemens karaktär och möjligheterna att lösa dem. En bidragande orsak är även massmedias egna redaktionella överväganden. Kommersialiseringen av journalistiken, som är en följd av upplagekonkurrensen, samt journalisternas kalkylerande maner att presentera sitt stoff originellt och dramatiskt leder obevekligen till en snedvridning.

I sitt val av ämnen som massmedia upptar till behandling prioriterar de därför sådana som kan tänkas sälja och sådana som kan ges en dramatisk touche. Ofta betyder detta i praktiken att den information som ges hänför sig till mer eller mindre udda händelser, som fixeras till en viss individ eller till en viss specifik situation som kan tänkas kittla mottagarens nyfikenhet. Redovisningar av strukturella faktorer och ofta komplicerade kausalförhållanden samt av den juridiska regleringens utformning och konsekvenser kvittas härvid ofta med en intetsägande generalisering.

\section{Straffrättsliga reformbehov och kriminalpolitiska opinionsyttringar}

Ett sätt att beskriva det spänningsfält som finns mellan den »allmänna opinion« som ges uttryck i massmedia och de rationella kriminalpolitiska besluten är att granska massmedias kriminalpolitiska debatt mot bakgrund av aktuella straffrättsliga reformbehov på basen av sakkunnig bedömning. ${ }^{13)}$

Den finska strafflagen (från år 1889) är idag klart föråldrad både till innehåll och form. ${ }^{14)}$ En av de mest centrala lagstiftningsreformerna i Finland är därför en totalreform av strafflagen. Genom denna reform borde kriminaliseringarnas tyngdpunkt läggas annorlunda än i den nugällande lagen. I denna ligger tyngdpunkten på handlingar som ej längre innebär samma hot mot människornas välfärd som de gjorde då lagen stiftades. För att ge lagen samma skyddsnivå som den tidigare har haft, bör såväl ny- som uppkriminaliseringar som av- och nedkriminaliseringar genomföras. Nykriminaliseringar och uppkriminaliserin- 
gar förutsätts framför allt till skydd för miljön, för arbete och social välfärd, mao inom det område som vanligen kallas ekonomisk brottslighet. ${ }^{15)}$

Trots att totalreformen av strafflagen ibland har betecknats som det största enhetliga lagstiftningsprojektet i Finland under detta århundrade, ${ }^{(6)}$ har reformarbetet erhållit påfallande liten uppmärksamhet i massmedia. Någon nämnvärd debatt uppstod inte ens i samband med den remissrond som genomfördes sedan Straffrättskommittén avlåtit sitt betänkande år $1977 .{ }^{17)}$ De senaste åren har överhuvudtaget ej utmärkt sig av någon större principiell kriminalpolitisk debatt i Finland. De kriminalpolitiska frågor som slagits upp på tidningarnas löpsedlar har haft sin grund i enskilda händelser.

Den ekonomiska brottsligheten har utan tvekan hört till de mest debatterade frågorna under de senaste åren. Utmärkande för denna debatt var särskilt till en början en stark polarisering. Medan företrädare för den kriminalvetenskapliga forskningen och den politiska vänstern betonade det allvarliga i denna brottslighet, lät företrädare för den politiska högern och för näringslivets organisationer påskina att problemet överdimensionerats. ${ }^{18)}$ Idag råder $\mathrm{i}$ detta avseende en betydligt större samstämmighet i bedömningarna.

Trots att den ekonomiska brottsligheten blivit livligt debatterad kan man ej säga att problemen i samband med denna brottslighet blivit allsidigt belysta $\mathrm{i}$ massmedia. Till en del beror detta redan på att benämningen »ekonomisk brottslighet« i den allmänna debatten nyttjats mycket frikostigt och utan önskvärd precision. Inte sällan har benämningen nyttjats för att beteckna helt traditionell förmögenhetsbrottslighet då denna förövats av flera gärningspersoner och uppvisat mer yrkesmässiga drag. ${ }^{191}$

Av den brottslighet på vilken termen ekonomisk brottslighet följdriktigt använd kan tillämpas, ${ }^{20)}$ har uppmärksamheten fördelats mycket ojämnt. Massmedias intresse har fokuserats fr $\mathrm{f}$ a till skattebrott och korruption, medan t.ex. de olika arbetsbrotten och miljöbrotten ägnats mindre intresse. Utmärkande för massmedias behandling av dessa ämnen har därtill varit en mycket snäv individcentrerad vinkling. Symtomatiskt i detta avseende är att den livligaste debatten kring miljöbrottslighet hänförde sig till ett udda fall av giftdumpning, där en enskild fysisk person (redan tidigare bestraffad för flera traditionella brott) kunde utpekas som huvudansvarig. ${ }^{21)}$ Den strukturella miljöbrottsligheten har i jämförelse med detta till sina skadeverkningar rätt begränsade fall granskats betydligt mindre. Den bild massmedia givit av den ekonomiska brottsligheten i Finland gör att den reducerats till enskilda missdåd av ett koppel utpekade fiffelherrar: „Gift-Jukka«, »Korvkungen«, »Metrons-Mutkolv« osv.

Ett av de centrala problemen i finsk kriminalpolitik är det höga fångtalet. I det aktuella reformarbetet är det därför också skäl att försöka lösa de problem 
som är förknippade med användningen av frihetsstraff. Målsättningen bör vara att minska de ovillkorliga frihetsstraffen och att utforma både reglerna om verkställighet $\mathrm{i}$ anstalt och utanför anstalt på ett sådant sätt som underlättar ett normalt socialt liv efter straffverkställigheten. ${ }^{22)}$

En minskning av fångpopulationen förutsätter bl a en lägre straffnivå. Detta kan uppnås genom generella regler rörande straffmätning och lägre abstrakta straffvärden för de vanligaste brottstyperna. En sänkning av den genomsnittliga konkreta straffnivån i Finland och särskilt en minskning av användningen av ovillkorliga frihetsstraff förefaller bl a på basen av internationella och historiska jämförelser, att vara möjlig utan att detta skulle leda till en ökning av brottsligheten. ${ }^{23)}$ I samband med totalreformen av strafflagen bör därför detta stå som ett av syftemålen.

Bland de fåtaliga kriminalpolitiska reformer som genomförts under de senaste åren är det skäl att särskilt nämna en som såsom ett syftemål hade en minskning av fångtalet, nämligen reformen av trafikfylleristadgandena år 1976. ${ }^{24)}$ Enligt tidigare lagstiftning var det primära straffet för rattfylleri, oberoende av konstaterad alkoholgrad i blodet, fängelse. Till följd av det starkt ökade antalet uppdagade rattfyllerifall ledda detta till att närmare $25 \%$ av dem som avtjänade ett frihetsstraff år 1974 gjorde det för rattfylleri.

I de nya stadgandena om trafikfylleri infördes fällande blodalkoholpromillegränser. Gränsen för rattfylleri sattes till 0,5 och gränsen för grovt rattfylleri till $1,5 \%$. Det primära straffet för rattfylleri blev böter, medan fängelse kvarstod som primärt straff för grovt rattfylleri. Straffmaximum sänktes dock i detta fall från 4 år till 2 år fängelse. Allt detta medförde en sänkning av straffpraxis och även en sänkning av landets fảngtal. ${ }^{25)}$

Bland de kriminalpolitiskt sakkunniga både i Finland och i de övriga nordiska länderna ansågs reformen som förnuftig och väl övervägd. ${ }^{26)}$ Minskningen i bruket av fängelsestraff fastslogs vara en uppenbar vinst både mätt i rent ekonomiska enheter och mätt $\mathrm{i}$ mänskligt lidande. Trots att antalet uppdagade rattfyllerifall även efter reformen fortsatte att öka, antog man bland de sakkunniga att reformen ej lett till en ökning av den faktiska rattfylleribrottsligheten. Forskningsresultat gav snarare vid handen att rattfylleriet totalt sett minskat. ${ }^{27)}$

Den syn som i massmedia förmedlats av reformen och dess konsekvenser är dock en helt annan. Särskilt under år 1983 framfördes såväl i press som i etermedia upprepade krav på en skärpning av straffen för rattfylleri. Som orsak angavs (uppenbarligen felaktigt) att de milda straffen för rattfylleri, särskilt de villkorliga fängelsestraff som i praktiken ofta utdömdes för grovt rattfylleri, hade lett till en stark ökning av rattfyllerifallen. Kraven på straffskärpning fördes fram även av framträdande politiker. Debatten kan sägas ha nått sin höjdpunkt genom att-president Mauno Koivisto, på samma sätt som hans 
företrädare Urho Kekkonen i ett tidigare nyårstal till republikens folk, i sitt tal nyårsdagen 1984 uttalade sin farhågor över »det ökade rattfylleriet «. ${ }^{28)}$

Det vore intressant att närmare analysera kampanjen för högre straff för rattfylleri för att därigenom få ett svar på frågan om detta är ett exempel på verklighetsskylande information på försorg av någon maktgrupp eller om fråga är om journalistik där verkligheten omedvetet under debattens lopp ändrat skepnad. Vilka de slutliga konsekvenserna av denna kampanj blir kan ännu ej bedömas. Möjligt är att debatten lämnar sina spår ej enbart i finsk lagstiftning och rättstillämpning, utan även i de övriga nordiska ländernas trafikfyllerireformer. ${ }^{29)}$

Straffen anses sällan i den allmänna debatten vara tillräckligt stränga. Det är därför inte förvånande att krav på ökade straff framställs såsnart någon brottstyp kommer i fokus. Krav i denna riktning kan ur den finländska debatten plockas fram i fråga om våld mot barn, våld i parförhållanden, gatu- och ungdomsvåld, videovåld och narkotikabrott. Ett enskilt fall av våldtäkt år 1982 ledde till en intensiv debatt och starka krav på en skärpning av straffen för detta brott. Särskilt starkt kritiserades domstolarna för en alttför mild domspraxis, där de utdömda straffen koncentreras till den tillämpliga latitudens nedre del och där t o $\mathrm{m}$ vissa villkorliga straff kan påvisas. ${ }^{30)}$

Detta allmänhetens krav på strängare straff och skarpare åtgärder mot brottslingar kan åtminstone till en del förklaras genom rädsla. Brottsligheten upplevs som ett konkret hot och risken för att själv bli offer för ett brott bedöms av en stor del av befolkningen som överhängande. ${ }^{31)}$ Det är uppenbart att massmedias sätt att behandla enskilda brott underblåser denna rädsla. Informationen och uppläggningen sker ofta i detta fall mindre med tanke på att ge en fullödig information och mer med tanke på att väcka sensation. Den uppförstorade och överdramatiska bild som massmedia härigenom ger av brott och brottslingar leder till att brottsligheten förefaller vara mer hotande än vad den objektivt sett är.

Den dagliga kriminalvården inom och utom straffanstalterna erbjuder rätt lite dramatiskt stoff. Det är därför inte förvånande att massmedia upptar ämnen som berör kriminalvården endast då något särskilt inträffat. Fråga är härvid vanligen om fall som innebär misslyckanden i kriminalvårdsarbetet, dvs våldsamma uppgörelser inom fängelset mellan fångar, fångrymningar och fångars brott under vistelser utanför anstalterna. Detta ämnesval medför att allmänhetens uppfattning om kriminalvården $\mathrm{i}$ dess helhet blir negativ. Även kriminalpolitiskt meningsfulla regler bedöms mycket kritiskt. Ett exempel på detta är den bild som man genom massmedia erhållit av systemet med fångpermissioner.

Ända sedan fångpermissioner infördes år 1971 har dessa utgjort ett ofta återkommande debattämne $\mathrm{i}$ massmedia. Såsnart en fånge befunnits ha gjort sig 
skyldig till brott medan han varit på permission har hela permissionssystemet starkt kritiserats. En väsentlig del av denna kritik har ursprungligen kommit från polisens sida. ${ }^{32)}$ Efter ett dubbelmord utfört av en fånge på permission i december 1983 och den publicitet som detta gavs kan man dock anta att kritiken även bland den stora allmänheten var mycket omfattande. ${ }^{33)}$

\section{Massmedias populism och beslutsfattarnas rationalism}

Massmedias behandling av brott och brottslingar med snäva vinklingar och starka effekter kan säkert försvaras med rent publicistiska argument. En kreativ journalistik har sina förespråkare lika väl som en journalistik som eftersträvar en absolut, objektiv återgivning av verkligheten. ${ }^{34)} \mathrm{Ju}$ mer journalistiken fjärmar sig från den journalistik som enbart redogör för vad som sker i samhället dess mer problematiskt blir det dock att foga in massmedia som en förmedlande länk mellan allmänhet och beslutsfattare. Detta i sin tur resulterar förmodligen i en mer fördjupad klyfta mellan populistiska tyckanden och beslutsfattarnas rationella överväganden.

Rent rationellt finns det goda skäl för att avfärda många av de åsikter som kommer till uttryck i massmedia såsom enbart tyckanden. ${ }^{35)}$ Även om en viss uppfattning mycket starkt kommer till synes vid behandlingen i massmedia av en kriminalpolitiskt relevant fråga kan uppfattningen nonchaleras med hänvisning till att den ej är tillräckligt väl underbyggd och strukturerad för att bli beaktad. ${ }^{36)}$ Även illa underbyggda tyckanden uppfattas dock som värdefulla och riktiga av dem som tycker dem. I en demokrati kan inte ens en rationell kriminalpolitik bedrivas enbart på de sakkunnigas villkor. För att kunna uppnå rättssäkerhet förutsätts ej enbart sakkunniga beslutsfattare utan även en sakkunnig allmän opinion. Denna kan åter skapas enbart genom en god journalistik.

\section{Massmedia och bevakningen av enskilda brottmål}

Det är ett välkänt faktum att brott är underhållande. Genomförda läsarundersökningar visar att notiserna i dagspressen om brott hör till de mest lästa - en insikt som de tidningar som erhåller sin huvudsakliga spridning genom lösnummerförsäljning utnyttjar genom att som förstasidesstoff använda nyheter om brott. ${ }^{37)}$ Åtminstone de större tidningsredaktionerna har särskilda redaktörer för att bevaka brott som utreds av polisen eller handläggs vid domstolarna. Också undersökande journalistik, där redaktörerna själva försöker finna och utreda brott som undgått de brottskontrollerande myndigheterna eller av dem undanhållits offentligheten - förekommer.

Detta massmedias intresse för och bevakning av de brottskontrollerande myndigheternas verksamhet har i grunden vissa positiva funktioner. Ett av rättsstatens kännetecken anses vara att rättsskipningen sker i offentlighet, utom i vissa undantagssituationer. ${ }^{38)}$ 
Detta följer redan därav att allmänhetens tilltro till rättsväsendet förutsätter insyn. Den egentliga rättegångens offentlighet har härvid den största betydelsen, men även information om polisens och de straffverkställande myndigheternas verksamhet är av vikt. Risken för negativ uppmärksamhet i massmedia utgör ett verksamt medel mot enskilda övergrepp.

Traditionellt har den allmänna offentligheten i lagskipningen realiserats genom att tillåta allmänheten att vara närvarande i rättssalen under rättegången. I praktiken är det dock sällsynt att enskilda medborgare, utan anknytning till målets parter och utan särskilt intresse för målets utgång, personligen utnyttjat denna rättighet att närvara vid själva domstolshandläggningen. Huvudansvaret för förmedling av information om vad som förevarit vid en domstol har därför massmedia. Den kontrollfunktion och den förtroendeskapande funktion som rättegångens offentlighet förutsätts ha, är mao idag helt beroende av massmedias verksamhet.

Förutom den betydelse som massmedias bevakning av rättegångarna i brottmål har för att upprätthålla offentlighetsprincipen har den offentlighet som massmedia ger brott och brottskontrollen en viktig betydelse för hela straffrättssystemet. För att straff skall ha avsedd funktion i ett system som grundas på straffets allmänpreventiva verkan, måste bestraffningen vara förenad med en viss information till allmänheten. Det räcker ej i detta fall med att information utgår om vilka gärningstyper som kriminaliserats och vilka abstrakta straffhot som fogats till de olika kriminaliseringarna. För att allmänheten skall kunna särskilja de straffbara gärningarna från tillåtet handlande förutsätts att normerna konkretiseras. Detta sker bl a i domstolarnas avgöranden av enskilda fall och av de redogörelser om dessa som lämnas i massmedia. Denna information gör straffbuden mer gripbara, den ger belägg för att straffhotet ej är tomma till sitt innehåll, utan grunder för reella konsekvenser för normstridigt handlande. ${ }^{39)}$ Information om förövade brott och bestraffade brottslingar påminner om att normerna existerar och att den rättsliga kontrollen fungerar.

I massmedias uppgift ingår även att upptäcka och påtala missförhållanden. En aktiv utforskande journalistik kan uppsnå resultat som är mycket betydelsefulla för hela samhället genom att avslöja korruption eller annat maktmissbruk. Ett bekant exempel på detta är den insats från massmedias sida som ledde till att den s k Watergateskandalen avslöjades. Mindre dramatiska exempel på att en aktiv journalistinsats bidragit till att rättvisa skipats $i$ enskilda fall kan anföras med lätthet. Bristen på inbyggda säkerhetsgarantier gör dock att risken för att rättsliga övertramp från massmedias sida är störst just på detta, den aktivt utforskande journalistikens, område. Med lätthet kan man därför även finna exempel på att maktmedia i sitt nit att upptäcka och avslöja brott själv begått brott. 


\section{Massmedias bevakning av rättsskipningen som en fara för rättssäkerheten}

Massmedias bevakning av enskilda brottmål kan bli problematisk. En alltför ivrig bevakning förenad med egna ställningstaganden om den riktiga bedömningen av målets fakta eller rättsliga sida kan utgöra ett hot mot rättssäkerheten. En inblandning från massmedias sida kan leda till att myndigheternas handläggning av fallet inte blir objektiv. Detta åter kan sägas resultera $\mathrm{i}$ att de involverade myndigheterna inte kan upprätthålla den oavhängiga ställning i förhållande till andra statsorgan och fria maktgrupper i samhället som förväntas av dem. Särskilt för domstolarna, som förutsätts vara helt oavhängiga, kan bevakning och kommentering av anhängiga brottmål leda till konfliktsituationer. För den misstänkta innebär publiciteten åter ett starkt ingrepp i eljest skyddad personlig integritet. Särskilt i de fall, då den för brottet misstänkta senare frikänns, kan denna stämpling i massmedia bli fatal. Sanktioner och remedia för rehabilitering kan sägas vara särskilt viktiga för att rätta till ojusta integritetskränkningar i samband med rättsvård.

Alla statsorgan som utför brottskontroll förväntas handla objektivt. Objektivitetsprincipen utgör en av de grundprinciper som styr åtgärderna och avgörandena under hela rättegången. Den grundläggande utgångspunkten vid en brottsutredning är presumtionen om den misstänktas oskuld. För de poliser som utför brottsutredningen gäller det därför att lika väl söka efter och verifiera bevismaterial, som talar för den misstänktas oskuld, som för bevismaterial som kan läggas till grund för ett sakfällande. ${ }^{40)}$ För åklagarmyndigheterna gäller det att utföra åtalsprövningen med beaktande av alla kända omständigheter. Beslut om åtal måsta grunda sig på starka skäl för misstanke om skuld. ${ }^{41)}$ Domstolen åter kan döma en åtalad person såsom skyldig till ett brott enbart om den i sin egen självständiga bedömning av målets fakta kommit till att den åtalades skuld bevisats så starkt att någon förnuftig misstanke om hans oskuld ej finns. ${ }^{42)} \mathrm{I}$ juridisk mening kan en person betecknas såsom brottsling först sedan han lagligen fällts för brott.

Alla involverade myndigheter förväntas handla självständigt och rationellt. Alla beslut fattas »efter bästa förstånd och samvete« utan att ovidkommande omständigheter tillåts påverka avgörandet. Idealbilden av omutlighet är domaren stödd på sin lag.

Även om ett av de syftemål som uppställs för massmedias verksamhet är att ge objektiv information om verkligheten, är objektivitetsprincipens betydelse för det praktiska journalistiska arbetet en annan än vad den är för de brottskontrollerande myndigheternas handlande. Kravet på att åstadkomma en säljande produkt står ofta $\mathrm{i}$ strid med försiktighet och vaga formuleringar. En avvaktande redogörelse för en persons möjliga skuld till en gärning, som eventuellt kommer att bedömas som ett brott, har ett betydligt lägre nyhetsvärde - 
och därigenom även marknadvärde - än ett tvärsäkert konstaterande att denna person gjort sig skyldig till brott.

Möjligheterna för en fri massmedieverksamhet har blivit allt mer begränsade. Massmedierna är ofta endast medel för samhällets maktgrupper för att realisera av dem uppställda syftemål. ${ }^{43)}$ Självklart är att en vinklad information i vissa fall bättre kan tjäna dessa syftemål än en information som är helt objektiv. Detta gäller även information om handläggningen av brottmål: $i$ en viss situation kan det ligga i massmedias intresse att genom sin bevakning av handläggningen av ett brott lägga upp informationen på ett sådant sätt att sakfällande framstår såsom rättvist/orättvist.

Fråga är härvid om ett medvetet försök att förmå behöriga myndigheter att ge avkall på objektivitetsprincipens krav. För allmänheten, som erhåller sin information genom massmedia, kan den objektiva sanningen framstå just såsom den framställning som massmedia gett och ej som den helhet av omständigheter som myndigheterna känt till. Ett avgörande som står i strid med massmedias bedömning framstår därför lätt såsom stötande för rättskänslan, vilket i sin tur kan påverka myndigheterna $\mathrm{i}$ deras avgörande. De presumerar (omedvetet) allmänhetens reaktion och parerar en negativ bedömning genom att tillmötesgå de förväntningar som ställs på avgörandet.

Bland de olika brottskontrollerande myndigheterna intar domstolarna en särställning. Dessa förutsätts alltid fungera oavhängigt. Domstolarnas oavhängighet anses utgöra den bästa garantin för rättssäkerheten. ${ }^{44)}$ Endast en rättsskipning som sker oavhängigt från annan politisk maktutövning i samhället anses kunna utövas objektivt. Försök att påverka domstolarna i deras handläggning av enskilda fall utgör därför ett hot mot en av rättsskipningens stöttepelare.

För att förhindra påverkan av domstolarna har man särskilt $\mathrm{i}$ engelsk rätt utformat regler som helt förbjuder en behandling av rättssaker i massmedia innan utslag getts. Överträdelser av dessa stadganden kan bedömas som »contempt of court« och bestraffas strängt. I de nordiska länderna finns det i Danmark ett liknande stadgande (Retsplejelov 1017 §). Enligt detta är det belagt med straff att lämna väsentligt oriktiga uppgifter om ett brottmål som ännu ej har avgjorts slutligt och att uttala sig $\mathrm{i}$ en sådan sak på ett sätt som är ägnat att "på uforsvarlig måde ... påvirke dommerne, domsmændene eller nævningerne med hensyn til sagens afgørelse «. ${ }^{45)}$ I Norge har man från advokat- och domarhåll framställt krav till justitiedepartementet om en lagstiftning i denna riktning och även i de andra nordiska länderna har frågan diskuterats. ${ }^{46)}$ Uppenbart är dock att rigorösa förbud i detta fall står i strid med yttrandefriheten och därför är svåra att förena med en liberal nordisk tradition. ${ }^{47}$

Förbudet mot en inblandning i domstolarnas handläggning av brottmål kan ses som en konsekvens av det traditionella tänkesätt som grundar sig på läran 
om maktens tredelning i samhället. Enligt detta tänkesätt är domstolarnas (och förvaltningsmyndigheternas) uppgift rätt enkel och mekanisk. Den består endast $i$ att tillämpa av andra organ uppställda normer, ej i att skapa nya normer.

Enligt ett annat tänkesätt, som också förespråkats, ${ }^{48)}$ är förbudet svårare att försvara. Om domstolarna uppfattas som organ som fattar samhälleliga beslut lika väl på grundval av tidigare formulerade normer, som på basen av den kunskap om samhället och allmän opinion som den beslutsfattande själv har, kan domstolarnas beslut ej särskiljas från andra politiska beslut. Då de politiska besluten åter förutsätter ett fritt meningsutbyte och en fri opinionsbildning som beaktas vid beslutsfattandet, är det kontroversiellt att utesluta denna form för politisk påverkan vid en typ av samhälleligt beslutsfattande men ej vid andra. Ju mer man betonar det politiska elementet i kriminalpolitiken och ju mer man ser samhället som en funktionell helhet, desto svårare är det att förbjuda fri debatt om brottmål som är anhängiga vid en domstol.

\section{Publicitet i massmedia som en oskälig kränkning av personlig integritet}

Gällande rättssystem förutsätter att brott och brottslingar ges viss publicitet. Ju svårare brottet är desto enklare är det att moraliskt försvara att lagbrytaren utlämnas för offentlighet. Det integritetsskydd som individerna tillförsäkrats särskilt under de senaste decennierna, har även medfört svåravvägda problem ifråga om samhällets rätt att begränsa integritetsskyddet för personer som misstänks eller lagförts för brott. ${ }^{49)}$

Då det gäller att fastställa när en publicerad beskrivning av ett brott utgör en kränkning av brottslingens integritet är det två uppsättningar av normer som är av betydelse: de officiella lagnormerna, främst i strafflagen, och de inofficiella pressetiska normerna som pressen själv utarbetat. De två normgrupperna kompletterar varandra: i alla nordiska länder har pressens självjustis utvecklats så långt att det primära sättet för konfliktlösning ofta ej är handläggning vid domstol, utan vid de organ som grundats för att tillämpa de pressetiska reglerna. ${ }^{50)}$ Svårare kränkningar, som förutsätter regelrätt bestraffning eller utdömande av skadestånd, bör dock handläggas vid de allmänna domstolarna med tillämpning av gängse lagstadganden. En närmare granskning av de två normgrupperna måste här förbigås. ${ }^{511}$

Problem med publicitet kring brott och brottslingar kan uppstå i alla skeden av rättegången. Risken för otillbörliga integritetskränkningar är dock större när publicitet ges om en misstänkt person redan innan åtalsprövning ägt rum. Ju svagare bevismaterialet är desto större är risken för att en oskyldig av massmedia utpekas såsom skyldig. Mot den stämpling som härigenom äger rum, är det svårt att finna verksamma medel för en pprättelse. Ej ens en frikännande dom vid domstol kan helt radera bort den fällande dom som givits av mass- 
media. Ej heller möjligheter som finns att väcka ärekränkningstalan eller skadeståndstalan ger i alla situationer ett tillräckligt rättsskydd. ${ }^{52)}$

Den tendens som kan iakttas åtminstone i Finland att ge omfattande publicitet åt brott som befinner sig i ett mycket tidigt skede av utredning, är farlig med tanke på individens rättsskydd. Bakom tendensen kan man se dels journalisternas jakt på upplagehöjande nyheter, men dels även en allians mellan brottsutredande myndigheter (särskilt polis) och massmedia. Alliansen är en följd av att vardera parten ser sig vara beroende av den andra. Journalisterna behöver sådan information som polisen har för att kunna publicera uppseendeväckande brottsnyheter. Polisen åter, som kämpar för en ökning av sina resurser och sin prestige, får genom massmedia den publicitet som detta förutsätter. Trots en existerande formell reglering om vilken information om brott under utredning som får lämnas, blir frestelsen stor för att upprätthålla ett informellt bytessystem, där bytesvaran är information mot positiv publicitet.

Problem med publicitet kring brott kan även vara anknutna till publicering av redan avgjorda brottmål. Särskilt personer som även eljest är utsatta för stor publicitet på grund av sin samhällsställning eller sitt yrke riskerar att bli uppmärksammade även i negativa sammanhang i större omfattning än vad som är samhälleligt motiverat. ${ }^{53)}$ Särskilt omotiverad kan en senkommen publicitet bli. Vare sig kriminalpolitiska skäl eller skäl som sammanhänger med ett upprätthållande av offentlighetsprincipen motiverar en behandling $\mathrm{i}$ massmedia av gamla brott och brottmålsdomar. Hänsyn till den domfällda och hans anförvanter talar i detta fall för stor återhållsamhet - med möjliga undantag för de fåtaliga fall som har ett verkligt värde för en historisk hävdateckning.

\section{Publicitet i massmedia som ett medel för särskilda syftemål}

Publicitet i massmedia kan även vara något som eftersträvas. Ett lagbrott under uppmärksammade former kan vara ett utmärkt medel för att uppnå allmän uppmärksamhet och om möjligt stöd av allmän opinion för visst syfte. Politiskt aktiva grupper med begränsade resurser för opinionsspridning kan på ett effektivt sätt använda massmedia för spridning av egna idér genom att begå lagstridiga handlingar. Exempel på detta är lätta att finna, inte minst bland samtidens terroristgrupper. De problem för en rättssäker brottskontroll som detta ger upphov till kan dock - som rätt extrema - här förbigås. ${ }^{54)}$ 


\section{HÄNVISNINGAR:}

1) Se Jareborg, Nils: Straff och rättvisa, i Påföljdsval, straffmätning och straffvärde. Rapport från ett forskarseminarium på Skokloster den 9-11 juni 1980. BR $\AA$-Rapport 1980:2, s. 29 fr.

2) Se t.ex. Träskman, P. O.: Har den finska kriminalpolitiken varit framgångsrik? JFT 1981 , s. $275 \mathrm{ff}$.

3) Straffrättskommitténs betänkande. Kom.bet. 1976:72, s. 48 ff.

4) Se Tolonen, Juha: Oikeudenmukaisuus ja legitimiteetti, i Studia Juridica 1982. Oikeudenmukaisuudesta (Red. Jukka Kekkonen). Helsinki 1982, s. 21 ff.

5) Se t.ex. Hemánus, Pertti \& Pietilä, Kauko: Seitsemän erää journalismista. Jyväskylä 1982, särsk. s. $49 \mathrm{ff}$.

6) Se Stenius, Yrsa: Koivisto och pressen. HbI 11.1.1984.

7) Se t.ex. Träskman, P. O. i i not 2 a a, s. 275 ff.

8) Se t.ex. Victor, Dag: Rättsmedvetande och straffvärde. Det 29:e nordiska juristmötet. Stockholm den 19-21 augusti 1981. Stockholm 1981 (särtryck), s. 1 ff. och Träskman, P. O.: Straffrättens stigma, i Lov og frihhet. Festskrift til Johs. Andenæs på 70-årsdagen, 7 september 1982. Oslo 1982, s. 377 ff.

9) Se Bondeson, Ulla: Rättsmedvetandet rörande brottens straffvärde och domarens straffmätning, samt, Lindén, Per-Anders \& Similä, Matti: Allmänhetens syn på olika handlingars gravhet och straffvärde, i i not 1 nämt verk, s. $54 \mathrm{ff}$.

10) Kyntäjä, Timo \& Laitinen, Ahti: Oikeussosiologia. Juva 1983, s. 187 ff. och där anförd litteratur.

11) Ibidem, s. 205 f.

12) Törnudd, Patrik: Oikeudenmukaisen rikosoikeudellisen kontrollijärjestelmän mahdollisuus, i i not 4 nämnt verk, s. 74 f. (Översättning från finskan av P. O. Träskman).

13) Granskningen begränsas här till debatten i massmedia i Finland och den gör ej anspråk på att vara fullständig.

14) Se Grönquist, Henrik: Om strafflagsreformen i Finland, i i not 8 nämnd festskrift, s. $139 \mathrm{ff}$.

15) Se Träskman, P. O.: Från varning till fängelse i fyratusentrehundraåttio dagar - om kriminalisering och värdering av brott, i Straff och rättfärdighet - ny nordisk debatt. Stockholm 1980, s. 51 ff.

16) Se Grönqvist, Henrik, i i not 14 a a, s. 150.

17) Om remissronden, ibidem, s. 145 f.

18) Se t.ex. Palanko, Kirsti: Taloudellisesta rikollisuudesta ay-liikkeen kannalta. Palkkatyöläinen 1982/49 och jämför med Vainio, Vesa: Valmisteltu puheenvuoro, i Taloudellinen rikollisuus. Lakimiesliiton koulutuskeskuksen julkaisusarja n:o 32 . Helsinki 1981, s. 31 ff.

19) Se även Taloudellisen rikollisuuden selvittelytyöryhmän mietintö Oikeusministeriön lainvalmisteluosaston julkaisu 6/1983, s. $7 \mathrm{ff}$.

20) Se Träskman, P. O.: Straffrätt och ekonomisk brottslighet, i Festskrift till Hans Thornstedt.Stockholm 1983, s. 695 ff. och Svensson, Bo: Ekonomisk kriminalitet. Göteborg 1983, s. 13 ff. 
21) Fallet har beskrivits utförligt av Aromaa, Kauko: Årets miljöbrott (Finland, 1982). Rapport presenterad vid NSfK:s forskarseminarium i kriminologi 1983 i Borgå, Finland.

22) Se Träskman, P. O. i i not 2 a a, s. 280 f.

23) Se Lappi-Seppälä, Tapio: Teilipyörästä terapiaan - piirteitä rangaistusjärjestelmän historiasta. VAHO 100. Vankeinhoidon historiaprojektin julkaisu 9/1982, särsk. s. $168 \mathrm{ff}$.

24) Reformen har beskrivits bl a av Träskman, P. O.: Bör rattfyllerist fă fängelse. Hbl 19.1.1982.

25) Se Träskman, P. O. i i not 2 a a, s. 280.

26) Se Lappi-Seppälä, Tapio: Rattijuopumusten rangaistustasoa ei ole aihetta muuttaa. HS 16.10.1983.

27) Ibidem, där det konstateras att kontrollen har ökat starkt, utan att de uppdagade fallen nämnvärt har ökat.

28) Om följderna av Urho Kekkonens utspel $\mathrm{i}$ rattfyllerifrågan och rattfylleribrottsligheten i allmänhet i Finland under 1950- och 1960-talet, se Jakkola, Risto \& Takala, Hannu: Rattijuoppous 1951-1970. Kriminologinen Tutkimuslaitos, sarja M:13. Helsinki 1971.

29) Se även Andenæs, Johs: Trafiklovgivning og almenprevensjon - særlig om promillekjøring. LoR 1983, s. 278 ff. särskilt s. 282 ff.

30) Se Törnudd, Patrik: Väkisinmakaamisrikosten rangaistukset eivät ole lieventyneet. Lakimiesuutiset 1982/4, s. 6 ff.

31) Se van Dijk, Jan J. M.: The Extent of Public Information and the Nature of Public Attitudes towards Crime, i Public Opinion on Crime and Criminal Justice. European Comittee on Crime Problems. Collected Studies in Criminological Research. Volume XVII, s. $7 \mathrm{ff}$.

32) Polisen har upprepat framställt krav på en betydligt större restriktivitet vid beviljandet av fångpermissioner. Frågan om fångpermissioner har även föranlett vissa muntliga riksdagsspörsmål. Kraven på större restriktivitet har dock tillbakavisats från justitieministeriets sida.

33) Under december 1983-januari 1984 gick en insändarstorm genom den finska pressen, där fångvårdsmyndigheterna starkt kritiserades. En eftermiddagstidning utkorade fångvårdens överdirektör K. J. Lång till »årets får« (motsats »årets lejon«) på basen av en läsargallup.

34) Se i not 5 anfört verk, s. $371 \mathrm{ff}$.

35) Se Törnudd, Patrik: Populismi ja kriminaalpolitiikka. Sosiologia 1982, s. 138 ff.

36) Se även Rock, Paul: Public Opinion and Criminal Legislation, i i not 31 nämnt verk, s. $163 \mathrm{ff}$.

37) Se Träskman, P. O.: Brottslingen som offentlig person, i Den personliga integriteten. Föredrag vid den XX:e nordiska studentjuriststämman i Lund 1977, s. 97 f.

38) Ibidem, s. $90 \mathrm{ff}$.

39) Ibidem, s. 92 ff.

40) Laento, Toivo \& Kotakoski, Paavo: Rikosten selvittämisestä. Helsinki 1981, s. 28 ff. 
41) Träskman, P. O.: Atalsrätt. De offentliga åklagarna, deras behörighet och uppgifter enligt gällande finsk rätt. Helsingfors 1980, s. 224 ff.

42) Se Bolding, Per Olof: Bevisbörda och beviskrav. Lund 1983, s. 17 ff.

43) Hemánus, Pertti: Journalistinen vapaus. Jyväskylä 1983, s. 24 ff.

44) Se t.ex. Holopainen, Toivo: Tuomioistuinten ja tuomareitten riippumattomuudesta ja riippuvuudesta. Juhlajulkaisu Paavo Kastari 1907, 13.11, 1977. Helsinki 1978, s. 87 ff.

45) Se även Gomard, Bernhard: Studier i den danske straffeprocess. København 1976, s. $397 \mathrm{ff}$.

46) I Norge har detta föreslagits av Harald Halvorsen. Se närmare LoR 1979, s. $337 \mathrm{ff}$.

47) Detta illustreras av de svårigheter som funnits vid tillämpning av det danska stadgandet i Retsplejeloven 1017 §. Se om dessa Ugeskrift for Retsvæsen 1982, s. 1022 f.

48) Se Rättsväsendekommissionens betänkande. Kom.bet. 1971:B 112, s. 9 ff.

49) Se Träskman, P. O. i i not 37 nämnt verk s. 87 f. och där anförd litteratur.

50) Se om dessa stadganden och deras tillämpning, t.ex.: Bratholm, Anders: Massmedia og ytringsfriheten, i i not 8 nämnd festskrift, s. 67 ff; Cars, Torsten: Kan man fă rätt mot pressen? SJT 1981, s. 1 ff.; Cars, Torsten \& Danowsky, Peter: Pressen inför rätta. Stockholm 1982; Grönqvist, Henrik: Pressetik och juridik, i i not 20 nämnd festskrift, s. $249 \mathrm{ff}$.

51) Se särskilt Grönqvist, Henrik i i not 50 a a.

52) Se Hov, Jo: Ærekrenkelser og personforfølgning i pressen som rettspolitisk problem. LoR 1982, s. 35 ff.

53) Se Träskman, P. O. i i not 37 a a, s. 97 ff.

54) Om dess särskilda problem se t.ex. The Media and Terrorism. A seminar Sponsored by The Chicago Sun-Times and Chicago Daily News. Chicago 1977.

Adresse: Professor, jur. dr. Per Ole Träskman

Institutionen för straff- och processrätt

Helsingfors Universitet

Regeringsgatan 11-13

SF 00100 , Helsingfors 10. 